\title{
The Relationship between Alcohol Consumption and Sleep Quality in the Elderly at Deli Serdang Regency
}

\author{
Helena Pryadina Hutauruk ${ }^{1}$, Fazidah Aguslina Siregar ${ }^{2}$, R. Kintoko Rochadi ${ }^{2}$ \\ ${ }^{1}$ Master Student of Public Health, Universitas Sumatera Utara, Medan, Indonesia \\ ${ }^{2}$ Lecturer in Faculty of Public Health, Universitas Sumatera Utara, Medan, Indonesia \\ Email: baikena@yahoo.com
}

\begin{abstract}
:
Sleep is one of the basic human needs that is useful for maintaining mental, emotional and health balance when awake. However, physical and physiological changes in the elderly coupled with health status and disease have an impact on the decline in the quality of sleep. The elders usually experience increased sleep latency, inability to initiate sleep, reduced sleep efficiency, sleeplessness, waking up faster, rhythm of sircadian disorders, and increased time for napping. The elders in Deli Serdang Regency chose to consume alcohol to overcome their sleep problems. This descriptive analytic study aims to analyze the relationship between alcohol consumption habits, especially palm wine and sleep quality of elders in Deli Serdang Regency. This study uses a cross sectional design with a quantitative approach. The population in this study were all elders living in Deli Serdang Regency. Sampling was done by purposive sampling technique. The sample size were 153 people and to anticipate the low response rate the sample was added by ten percent to 164 elderly people. The results showed that from simple regression logistic test, it was obtained that the palm wine consumption variable with $p$ score $=0.023$ PR $=12.115$ (95\% CI $1.421-103.276)$. Alcohol consumption factors were factors that are very likely to be changed by controlling excessive drinking (palm wine) alcoholic behavior. It would be better if the alcohol consumption habits (palm wine) were stopped because remembering the long-term effects of alcohol which not only affect the quality of sleep to be bad but also can affect one's health status.
\end{abstract}

Keywords:

alcohol consumption; sleep quality in the elderly

\section{Introduction}

Supporting a good quality of life, according to Maslow's basic human needs hierarchy, physiological needs are the most powerful basic needs (Aziz, 2006). One of the physiological needs is the need for sleep.

Understanding the quality of sleep is not the same as the quantity of sleep. Stanley \& Beare (2006) say that the quantity of sleep that is the length of sleep and the amount of sleep differ from the quality of sleep which is the efficiency of sleep, how long sleep is proportional to the length of a person lying in bed. Sleep quality is more to a feeling of satisfaction with one's sleep after waking up from sleep in other words sleep is someone's satisfaction with sleep that if the quality is good someone does not look tired, easily aroused and agitated, apathetic and weak, black circles in the eye area, swollen eyelids, eyes sore, reddened conjunctiva, loss of concentration, headache and drowsiness or frequent yawning (Hidayat, 2012).

The decrease in sleep quality in the elderly is caused by physical and physiological changes in the elderly. Changes in the elderly neurological system will directly reduce the number of neurons in the central nervous system which ultimately causes a decrease in neurological function, which affects the distribution of neuropeptides, which are substances to stimulate sleep and also decreases, thereby changing the sleep patterns of the elderly (Stanley \& Beare, 2006). Neuropeptides are transmitters produced by the brain found in nerve networks and function as 
regulators and signs and as neurotransmitters / communication links between neurons. When the neuropeptide decreases, it will result in neurons not delivering impulses / messages properly, thereby affecting the incidence of sleep in the elderly (Stanley \& Beare, 2006; Tsou, 2013).

The health status of the elderly also affects the sleep quality of the elderly. Elderly who suffer from hypertension will certainly consume certain drugs that can reduce sleep quality (Asmadi, 2008). According to the World Health Organization (WHO) and The International Society of Hypertension (ISH) in 2003 and of the 600 million people with hypertension in all parts of the world, there were three million people who died. Based on data from the WHO's Global Status Report on No communicable Disease in 2010 showed that as many as 40 percent of developing countries have hypertension, for Southeast Asia as much as 36 percent.

Riskesdas data for 2018 showed that the prevalence of hypertension in Indonesia based on measurements of the population aged less than 18 years by 34.1 percent increased from Riskesdas Data in 2013 which was 25.8 percent. Based on data from the Health Office of North Sumatra Province in 2016, the results of measurements carried out in the primary health care unit, private government, inside and outside the building of the population aged over 18 years are known that hypertension sufferers reach 50,162 residents with a greater proportion of women of 27,021 the population with age above 55 years is 22,618 . Based on the data above, it will be a big problem if the handling and control is not done properly which can result in decreased productivity and increased mortality due to complications of hypertension (Sumatra Provincial Health Office, 2016).

Data from the Deli Serdang Regency Health Office in 2016 from 182,895 residents aged over 18 years who had taken blood pressure measurements obtained 24,793 people (13.5\%) who suffer from hypertension. This figure is quite large and countermeasures should be made. The results of Alfi \& Yuliwar's research (2018) showed that there was a strong relationship between sleep quality and blood pressure in hypertensive patients in the work area of Mojolangu Public Health Center in Malang City and had a strong relationship of 0.649. So it can be concluded that patients with poor sleep quality will be more at risk of suffering from hypertension.

To overcome the problem of decreasing sleep quality in the elderly, people in Deli Serdang Regency usually consume alcohol. This condition is strengthened by the existence of a myth in the community which states that drinking alcohol can make it easier to sleep. Alcohol consumed by the public is a type of traditional alcohol called palm wine.

Based on the Basic Health Research (Riskesdas) in 2018, nationally the proportion of alcohol drinkers in the past month was 3.3 percent while the proportion of alcohol drinkers in North Sumatra Province was above the national figure of more than five percent. The proportion of consumption drinks of alcoholic drinks and types of alcoholic drinks in the population above the age of ten years is dominated by traditional drinks by 38.7 percent (Riskesdas, 2018).

Palm wine is consumed almost every day and they call it the term palm wine afternoon. From a survey conducted in one village in Deli Serdang Regency, Tangkahan Village, out of 64 elderly people in the village, there were 22 elderly men who all had the habit of consuming alcohol to get good quality sleep.

Palm wine is a traditional alcoholic beverage which is obtained from a sugar-containing liquid that is tapped from the sugar palm plant (arenga pinnata) called sap and then fermented and mixed with raru which has an alcohol content of about 5.1 to 9.9 percent (Suryanto \& 
Nurbaya, 2016). This alcohol has a sedative effect which increases the onset of sleep which makes a person more likely to fall asleep. But on the other hand, alcohol consumption in the long run can disrupt the rhythm of sircadian so that it reduces the quality of one's sleep.

Palm wine has an important position as a drink that is usually consumed every day for Toba Batak men and has an important role in the traditions and rituals of Batak Toba customs. Palm wine is also a means to realize Dalihan Na Tolu's friendship, which is a term given to three respected lines of relationship within the Batak family (IKEGAMI, 1997).

This study seeks to explore people's assumptions about wine as a drink that improves sleep quality and the relationship between intrinsic factors, blood pressure, and alcohol consumption habits with sleep quality while exploring the low level of public knowledge about the effect of palm wine on sleep quality, lack of awareness for health, tradition and belief which can actually be detrimental to their health condition especially in Deli Serdang Regency.

\section{Research Methods}

The purpose of this study was to analyze the relationship between alcohol consumption and sleep quality in the elderly at Deli Serdang Regency. This type of research was a correlation study with cross sectional design. The population in this study were all elderly living in Deli Serdang Regency. Sampling was done by purposive sampling technique. The sample size was 153 people and to anticipate the low response rate the sample was added by ten percent to 164 elderly people. Variables in the study consisted of alcohol consumption and sleep quality in the elderly. Data collection was carried out by distributing questionnaires. Statistical analysis was performed using the Simple Regression Logistic test.

\section{Discussion}

\subsection{Result}

\section{a. The Overview of Alcohol Consumption and Sleep Quality in the Elderly}

The results of the study there are 157 respondents (95.7 percent) who fall into the category of having moderate alcohol consumption habits that are one to four bottles a day and there are seven respondents ( 4.3 percent) who have mild alcohol consumption habits that are less than one bottle a day. The majority of respondents who had poor sleep quality were 106 respondents (64.6 percent) and 58 respondents who had good sleep quality ( 35.4 percent). The percentage of alcohol consumption and sleep quality of the elderly is shown in table 1.

Table 1. The percentage of alcohol consumption and sleep quality in the elderly

\begin{tabular}{ccc}
\hline Variable & Total (person) & Percentage \\
\hline Alcohol consumption & & \\
Standard (<1 bottle/day) & 7 & 4,3 \\
High (1-4 bottle/day) & 157 & 95,7 \\
Total & $\mathbf{1 6 4}$ & $\mathbf{1 0 0}$ \\
\hline Sleep Quality & & \\
Good & 58 & 35,4 \\
Bad Total & 106 & 64,6 \\
$\quad \mathbf{1 6 4}$ & $\mathbf{1 0 0}$ \\
\hline
\end{tabular}




\section{b. The Relationship between Alcohol Consumption and Sleep Quality in the Elderly}

The results of a cross tabulation between alcohol consumption and sleep quality in the elderly at Deli Serdang Regency showed that the majority of elderly people who consumed light or less than one bottle had good sleep quality (85.7 percent) and the majority of elderly people who consumed moderate wine or one to four bottles had poor sleep quality (66.9 percent). Analysis of alcohol consumption on the quality of sleep in the elderly at Deli Serdang Regency obtained a p score of 0.023 with an RP score of 12.115 (95\% CI 1.421 - 103.276) which can be interpreted that there is a relationship between consumption of palm wine to the quality of sleep in the elderly in Deli Serdang Regency.

Table 2

\begin{tabular}{lcclc}
\hline \multirow{2}{*}{ Variable } & \multicolumn{5}{c}{ Sleep Quality } \\
\cline { 2 - 5 } & \multicolumn{2}{c}{ Good } & \multicolumn{3}{c}{ Bad } \\
\cline { 2 - 5 } & $\mathbf{n}$ & $\mathbf{0}$ & $\mathbf{n}$ & $\mathbf{0}$ \\
\hline Alcohol Consumption & \multicolumn{3}{c}{1} & 14,3 \\
Standard & 6 & 85,7 & 1 & 66,9 \\
High & 52 & 33,1 & 105 & \\
\hline $\mathrm{P}=0,023 ; \mathrm{PR}=12,115$ & $(95 \%$ CI $1,421-103,276)$ \\
\hline
\end{tabular}

\subsection{Discussion}

Based on the results of the study there were 157 respondents (95.7 percent) who were included in the category of having moderate (palm wine) alcohol consumption habits, namely one to four bottles a day. The results of a cross tabulation between alcohol consumption (palm wine) and the quality of sleep in the elderly in Deli Serdang Regency showed that the majority of elderly people who consumed light alcohol or less than one bottle had good sleep quality $(85.7 \%)$ and the majority of elderly people who consumed alcohol (palm wine) moderate or one to four bottles have poor sleep quality (66.9 percent). Bivariate analysis between alcohol consumption (palm wine) to the quality of sleep in the elderly in Deli Serdang Regency using simple regression logistic test obtained p score $=0.023$ with a score of RP $=12.115(95 \%$ CI 1,421 - 103,276) which can be interpreted that there is a relationship between alcohol consumption (palm wine) on the quality of sleep in the elderly in Deli Serdang Regency.

The study results of the Chueh et al (2009) also showed that elderly Taiwanese Aboriginal women who consumed alcohol had poor sleep quality in the domain of things that disturbed sleep, subjective sleep quality, and drowsiness during the day compared to elderly people who did not consume alcohol. In line with the study of Park et al (2015) significantly alcohol consumption in men is associated with subjective sleep quality $(p=0.005)$, sleep duration $(p=0.047)$, and sleep disturbance $(p=0.048)$ and there is no relationship with sleep latency sleep efficiency or sleepiness during the day. But in contrast to the Ancoli-Israel \& Roth study (2000) reported that people with insomnia using alcohol helped them sleep for the past year and 67 percent of respondents in this study reported improved sleep quality. The same thing was also stated in Roehrs \& Roth's (2016) study that alcohol with high doses in healthy people would interfere with sleep but alcohol with low doses in people with insomnia might be more beneficial.

The results of a cross tabulation between education and sleep quality in the elderly indicate that the majority of the elderly with a background in primary education (SD) have poor sleep quality (64.3 percent) and the majority of the elderly with a secondary education background (junior/senior high school) have poor sleep quality as well (65.3 percent). In the analysis of the relationship between the education of the elderly who consume alcohol on sleep quality in Deli Serdang District, a p score of 0.906 with an RP score of 1.043 (95\% CI 0.517 - 
2.103) can be interpreted that there is no relationship between the education of the elderly who consume alcohol on sleep quality in Deli Serdang Regency.

The education of the elderly who has a low majority also influences the consumption behavior of the elderly palm wine. So education indirectly affects the quality of sleep in the elderly. The lack of education and knowledge of the elderly will result from the consumption of palm wine which ultimately affects the drinking habits of the elderly.

The results of the cross tabulation between income and sleep quality of the elderly indicate that the majority of the elderly with incomes below the minimum wage (less than or equal to 2.3 million) have poor sleep quality (64.3 percent) and the majority of the elderly with income above the minimum wage (more than 2.3 million) have poor sleep quality too (64.7 percent). Analysis of the relationship between the income of the elderly who consume alcohol to sleep quality in Deli Serdang Regency obtained a p score of 0.966 with an RP score of 1.019 ( $95 \%$ CI 0.436 - 2.381) which can be interpreted that there is no relationship between the income of the elderly who consume alcohol on sleep quality in Deli Serdang Regency.

The elderly income that the majority of which is above the minimum wage, also influences the consumption behavior of the elderly. The average respondent works daily in the fields and lives with family so it can be concluded that the elderly have economic aspects that guarantee the life of the elderly.

\section{Conclusion}

The results showed that there was a strong relationship between alcohol consumption (palm wine) with the quality of sleep in the elderly at Deli Serdang Regency. The interpretation obtained from the study is that consumption of alcohol (palm wine) is having a chance of poor sleep quality in the elderly ten times greater than consumption of alcohol (palm wine) mild. Alcohol consumption factor was factor that very likely to be changed by controlling excessive drinking (palm wine) alcohol behavior. It would be better if the alcohol consumption habits (palm wine) were stopped because remembering the long-term effects of alcohol which not only affect the quality of sleep to be bad but also can affect one's health status.

\section{References}

Alfi, W.A., and Yuliwar, Roni. Hubungan Kualitas Tidur dengan Tekanan Darah Pasien Hipertensi di Puskesmas Mojolangu Kota Malang Keperawatan Poltekkes Kemenkes Malang Jurnal Berkala Epidemiologi, FK. Unair Volume 6 Nomor 1, Januari 2018, Hlm. 25-36

Ancoli-Israel, S. and Roth, T. 2000. Characteristics of Insomnia in the United States: Result of the 1991 National Sleep Foundation Survey. I. Sleep 22:S347 - S353

Asmadi. 2008., Teknik Prosedural Keperawatan : Konsep dan Aplikasi Kebutuhan Dasar Klien, Jakarta: Salemba Medika.

Aziz, AA. 2008. Keterampilan Dasar Praktik Klinik Kebidanan. Edisi 2, Jakarta : Salemba Medika.

Chueh, K., Yang, M., Chen, C., Chiou, S., 2009. Poor Sleep Quality and Alcohol Use Problems Among Elderly Taiwanese Aboriginal Women. International Psychogeriatrics (2009), 21:3,593-599[serialonline].

http://www.edoc.ypu.edu.tw:8080/paper/nurse/Other/Poor\%20sleep\%20quality\%20an d\%20alcohol\%20use\%20problems\%20among.pdf [2 November 2018]. 
Hidayat, A. A., 2012. Pengantar Kebutuhan Dasar Manusia : Aplikasi Konsep dan Proses Keperawatan, Jakarta: Salemba Medika.

Ikegami, S., 1997. Palm wine in The Batak Sosiety : A Preliminary Report on the Socio-Cultur Aspect of Palm Wine Consumption. Annual Report of the University of Shizuoka, Hamamatsu College, Jepang.

Dinas Kesehatan Pemerintah Kabupaten Deli Serdang. 2016. Profil Kesehatan Kabupaten Deli Serdang. Deli Serdang

Dinas Kesehatan Propinsi Sumatera Utara.Profil Kesehatan Propinsi Sumatera Utara. 2016. Medan

Park, Soon-Yeob., Oh, M., Kim, J. 2015. The Effects of Alcohol on Quality of Sleep. Korean Journal of Family Medicine. Diakses dari https://www.ncbi.nlm.nih.gov/pmc/articles/PMC4666864.

Riskesdas., 2018. Badan Penelitian dan Pengembangan Kesehatan Kementrian Kesehatan RI. Jakarta

Roehrs, T. and Roth, T. 2016. Sleep, Sleepiness, Sleep Disorders and Alcohol Use and Abuse. Sleep Med Rev2001; 5:287-97

Stanley, M., dan Beare, P.G., 2006. Buku Ajar Keperawatan Gerontik, Jakarta: EGC.

Suryanto., \& Nurbaya, S., 2016. "Pemeriksaan Kadar Alkohol Dalam Minuman Palm wine." Jurnal Farmanesia Volume 1(November 2018): 22-23.

Tsou, Eng-Ting., 2013. Prevalence And Risk Factors For Insomnia In Community- Dwelling Elderly In Northern Taiwan. Journal of Clinical Gerontology \& Geriatrics. 